\title{
PELATIHAN KONSELOR SEBAYA PADA SISWA KELAS XI SMAN 1 WONOGIRI MENGGUNAKAN ZOOM MEETING DI ERA PANDEMI COVID-19
}

\author{
Mahmuddah Dewi Edmawati ${ }^{1}$, Aldila Fitri Radite Nur Maynawati ${ }^{2}$ Awik Hidayati ${ }^{3}$ \\ ${ }^{1,2,3}$ FKIP, Universitas Veteran Bangun Nusantara Sukoharjo, Surakarta \\ Email: mahmuddahdewi@gmail.com ${ }^{1}$
}

\begin{abstract}
The purpose of peer counselor training activities for class XI students of SMAN 1 Wonogiri using a zoom meeting in the Covid-19 pandemic era is to provide information about peer counselors and provide peer counselor skills to students at SMAN 1 Wonogiri. This training also provides information on guidance and counseling services, increases the ability to become peer counselors, and makes peer counselors an extension of counseling services in schools to help solve peer problems. Peer counselor training were carried out in 4 stages. Phase 1, by sharing and questioning, several training participants were asked to share their experiences while receiving guidance and counseling services during the Covid-19 pandemic. Stage 2 is the provision of material about peer counselors. The material is delivered in the form of lectures on peer counselor materials, discussions, provides examples of peer counselor activities through videos and carries out practices in the form of role-playing as a counselor and counselee. Stage 3 is the practice and implementation of peer counselor guidance and stage 4 is to evaluate the results of the peer counselor practice. The results of peer counselor training include improving the image of counseling guidance services through peer counseling activities, providing interpersonal skills to students, increasing knowledge and skills to become peer counselors so that students can become partners for guidance and counseling teachers.
\end{abstract}

Keywords: peer counselor training, zoom meeting, covid-19 pandemic era

\begin{abstract}
Abstrak. Tujuan dari kegiatan pelatihan konselor sebaya pada siswa kelas XI SMAN 1 Wonogiri menggunakan zoom meeting di era pandemi covid-19 adalah memberikan informasi mengenai konselor sebaya dan memberikan ketrampilan konselor sebaya kepada siswa di SMAN 1 Wonogiri. Pelatihan ini juga memberikan informasi mengenai layanan bimbingan dan konseling, meningkatkan kemampuan menjadi konselor sebaya, dan menjadikan konselor sebaya sebagai perpanjang tangan layanan BK di sekolah untuk membantu memecahkan permasalahan teman sebaya. Pelatihan konselor sebaya dilaksanakan dalam 4 tahap. Tahap 1 dengan dengan sharing dan tanya jawab beberapa peserta pelatihan diminta untuk menyampaikan pengalaman selama menerima layanan bimbingan dan konseling di masa pandemi covid-19. Tahap 2 yaitu pemberian materi mengenai konselor sebaya. Materi disampaikan dalam bentuk ceramah mengenai materi konselor sebaya, diskusi, memberikan contoh kegiatan konselor sebaya melalui video dan melaksanakan praktik dalam bentuk role-playing sebagai konselor dan konseli. Tahap 3 yaitu praktik dan pendampingan pelaksanaan konselor sebaya dan tahap 4 yaitu mengevaluasi hasil dari praktik konselor sebaya. Hasil kegiatan pelatihan konselor sebaya antara lain meningkatkan citra layanan bimbingan konseling melalui kegiatan konseling sebaya, memberikan ketrampilan interpersonal kepada siswa, menambah pengetahuan dan keterampilan menjadi konselor sebaya sehingga siswa dapat menjadi partner guru bimbingan dan konseling.
\end{abstract}

Kata kunci : pelatihan konselor sebaya, zoom meeting, era pandemi covid-19

\section{PENDAHULUAN}

Bimbingan dan Konseling memiliki peran yang penting dalam memandirikan siswa terkait pencapaian tugas perkembangan (Habsy, 2017). Tugas perkembangan terbagi menjadi tugas perkembangan anak, remaja, dan dewasa (M. Ridha, 2012). Siswa SMA kelas XI berada dalam tahap perkembangan masa remaja. Masa remaja indentik dengan adanya ketertarikan dan ikatan terhadap teman sebaya yang sangat kuat.
Remaja menganggap teman sebaya merupakan salah satu figur penting (significant others) yang sangat berperan dalam aspek kehidupannya (Salmiati et al., 2018). Adanya kenyamanan bercerita maupun mengungkapan permasalahan dengan teman sebaya dikarenakan orang dewasa dianggap tidak selalu memahami pola pikir dan keinginan seorang remaja. Selain itu adanya perasaan malu, canggung dan kurang nyaman membuat remaja lebih nyaman meminta solusi 
permasalahan kepada teman sebaya dibandingkan kepada orang dewasa maupun konselor.

Karakteristik remaja dengan ketertarikan dan ikatan terhadap teman sebaya yang sangat kuat dapat diimplementasikan untuk pelaksanaan layanan Bimbingan dan Konseling (Sarmin, 2017). Selama ini siswa mengasumsikan bahwa yang bertugas untuk membantu mengatasi masalah remaja di sekolah hanyalah guru BK atau konselor. Padahal teman sebaya dapat dijadikan penguatan layanan Bimbingan dan Konseling yang dilaksanakan guru BK. Teman sebaya dapat dibekali ketrampilan dasar konselor sebaya (peer counseling) sehingga pemberian saran yang diberikan dapat lebih efetif untuk menyelesaikan permasalahan siswa. Konseling sebaya merupakan proses pemberian bantuan berupa konseling sebaya yang dilaksanakan oleh siswa (Shohib et al., 2016). Konselor sebaya merupakan siswa yang secara sukarela ingin membantu teman sebaya melalui kegiatan konseling sebaya. Penggunaan istilah konselor sebaya seringkali dimaknai sama dengan konselor professional (Suranata, 2013). Oleh karena itu perlu ada penjabaran mengenai konselor sebaya. Konselor sebaya dapat diartikan sebaga agen pembantu guru BK dalam melaksanakan layanan bimbingan dan konseling di sekolah.

Namun demikian siswa masih merasa enggan meminta bantuan guru bimbingan dan konseling di sekolah untuk meminta saran, menceritakan masalah, menyelesaikan masalah maupun berkonsultasi masalah karir (Salmiati, 2018). Terkadang siswa lebih merasa nyaman jika bercerita dan meminta saran permasalahan dari teman sebaya. Hasil studi pendahuluan melalui google form yang dilakukan terhadap 50 orang siswa kelas XI SMA N 1 Wonogiri diperoleh data bahwa tidak semua siswa bersedia untuk berbagi cerita dengan konselor sekolah terutama untuk hal-hal pribadi. Siswa lebih nyaman untuk bercerita dengan teman sebaya karena remaja memiliki kecenderungan personal fable. Personal fable yaitu keyakinan bahwa hanya remaja yang mengalami pengalaman unik, bukan orang dewasa lain (Zamroni \& Rahardjo, 2015). Oleh karena itu, penguatan melalui konseling sebaya (peer counseling) dipandang efektif untuk dilakukan Konseling sebaya merupakan serangkaian kegiatan yang berasaskan layanan bimbingan dan konseling dengan tujuan membantu dan memperhatikan teman sebaya sehingga permasalahan siswa dapat terselesaikan dengan baik dan pencapain tugas perkembangan dapat tercapai. Konseling sebaya memberikan kesempatan kepada siswa untuk mendapatkan pemahaman, mengembangkan ketrampilan konselor sebaya dan mendapatkan pengalaman yang bermakna (Prasetiawan, 2016). Pembentukan konseling teman sebaya pada remaja dapat ditempuh dengan memberikan pelatihan kepada siswa terpilih untuk menjadi konselor sebaya.

Mengingat saat ini era pandemi covid-19 masih berlangsung di Indonesia maka pelaksanaan pelatihan konselor sebaya dapat dilaksanakan secara daring melalui zoom. Berdasarkan pemaparan diatas urgensi Pelatihan Konselor Sebaya Pada Siswa SMAN 1 Wonogiri menggunakan zoom di era pandemi covid-19 sebagai inovasi pelaksanaan layanan BK dengan memanfaatkan keterikatan dan hubungan teman sebaya yang kuat pada remaja untuk mengatasi permasalahan yang dialami. Anak - anak populer memiliki sejumlah kemampuan sosial yang membantu mereka disukai (Santrock, 2002). Melalui kegiatan konseling sebaya tujuan bimbingan dan konseling dalam membantu memfasilitasi pencapaian tugas perkembangan siswa dapat berjalan optimal

Berdasarkan analisis situasi pada latar belakang tersebut beberapa hal yang dianggap pengusul sebagai masalah prioritas yang harus ditangani yaitu pemberian layanan bimbingan dan konseling di era pandemi covid-19 sulit dilaksanakan secara konvensional, pelaksanaan layanan bimbingan dan konseling perlu memanfaatkan media virtual conference atau secara daring dan peserta didik/ konseli lebih nyaman meminta bantuan kepada teman sebaya dibandingkan konselor (A. A. Ridha, 2019). Berdasarkan permasalahan yang dialami oleh mitra, tim pelaksana pengabdian kepada masyarakat menargetkan beberapa solusi. Solusi tersebut berupa kegiatan pelatihan dilakukan dengan strategi kronologi atau bertahap. Pelatihan diberikan dengan sharing, tanya jawab 
dan pemberian materi, pengamatan video, praktik konselor sebaya dengan role playing, mengevaluasi hasil praktik. Pelatihan dilaksanakan secara daring dari rumah masingmasing dan tidak dipungut biaya. Pelatihan konseling sebaya dilakukan oleh tim dosen Bimbingan dan Konseling Univet Bantara Sukoharjo yang berkompeten dalam bidang permasalahan mitra. Adapun rencana target capaian luaran Pengabdian kepada Masyarakat Kompetitif Klaster Pelatihan Konseling Sebaya menggunakan zoom pada siswa SMAN 1 Wonogiri adalah publikasi ilmiah pada Jurnal Terapan Abdimas ber ISSN 2502 - 2806, E-ISSN $\begin{array}{lllll} & 2502 & - & 2786 & \text { ( http://e- }\end{array}$ journal.unipma.ac.id/index.php/jta ).

\section{METODE PELAKSANAAN}

Metode yang digunakan adalah metode pelatihan yaitu digunakan untuk kegiatan yang melibatkan a) penyuluhan tentang substansi kegiatan konselor sebaya yang disertai dengan demonstrasi atau percontohan untuk realisasinya, b) pelatihan dalam praktik melaksanakan konselor sebaya, c) pembentukan kelompok konselor sebaya, d) penyediaan jasa layanan bersertifikat kepada siswa perserta pelatihan konselor sebaya. Kegiatan pelatihan konselor sebaya pada siswa kelas XI SMA Negeri 1 Wonogiri Kabupaten Wonogiri Provinsi Jawa Tengah dilaksanakan secara daring menggunakan zoom meeting. Pelaksanaan kegiatan dilaksanakan tanggal 02 Desember - 05 Desember 2020.

Mitra dalam kegiatan pengabdian masyarakat dalam kegiatan pelatihan konselor sebaya adalah siswa kelas XI SMAN 1 Wonogiri sebanyak 10 orang siswa yang diwakili oleh 10 anggota OSIS Kelas XI SMAN 1 Wonogiri. Pemilihan siswa yang menjadi perwakilan setiap kelas berdasarkan pertimbangan siswa yang menjadi sasaran dalam kegiatan pelatihan konselor sebaya adalah siswa yang memiliki kemampuan interpersonal yang tinggi dibandingkan dengan teman-teman yang lainnya yang ada di dalam kelas dan diharapkan adanya keterwakilan siswa yang berjenis kelamin lakilaki dan siswa yang berjenis kelamin wanita. Selain itu siswa yang dipilih merupakan siswa dengan kemampuan komunikasi dan ketrampilan interpersonal yang baik sehingga menjadi salah satu kriteria konselor sebaya. Adapun yang menjadi instruktur dalam kegiatan ini adalah dosen-dosen Prodi Bimbingan dan Konseling Univet Bangun Nusantara Sukoharjo yaitu Dra. Awik Hidayati, M.Si, Aldila Fitrie R.N.M., M.Pd dan Mahmuddah Dewi Edmawati, M.Pd.

Pelatihan konselor sebaya pada siswa kelas XI SMAN 1 Wonogiri menggunakan zoom meeting di era pandemi covid-19 dilaksanakan dengan cara: a) Ceramah/Pemberian Informasi; Kegiatan ini dimulai dengam pemberian informasi kepada siswa peserta pelatihan konselor sebaya terkait materi mejadi konselor sebaya. Selanjutnya pertemuan pertama dilaksanakan dengan sharing dan tanya jawab beberapa peserta pelatihan diminta untuk menyampaikan pengalaman selama menerima layanan bimbingan dan konseling di masa pandemi covid-19, hal ini dilakukan meningat pelaksanaan layanan BK di masa pandemi covid sulit dilaksanakan secara konvensional. Kegiatan ini dilakukan dengan harapan siswa memiliki pemahaman yang baik terkait dengan konselor sebaya agar terjadi kesepahaman antara pemateri dengan peserta. b) Pemutaran Video Konselor Sebaya, untuk memberikan pemahaman lebih lanjut mengenai konselor sebaya maka siswa peserta pelatihan mengamati dan mempelajari video praktik konselor sebaya, c) Role Play; yaitu kegiatan bermain peran yang dirancang dengan tujuan memberikan pemahaman dan gambaran dalam suatu skenario mengenai kegiatan konselor sebaya. role play peserta ditempatkan pada situasi menjadi konselor dan konseli untuk mendapatkan pengalaman baru dan nyata tentang proses konseling sebaya. d) Focused Group Discussion (FGD); merupakan suatu teknik diskusi kelompok yang bertujuan untuk media sharing informasi dan permasalahan yang ingin didiskusikan dalam kegiatan kelompok. Pelaksanaan FGD peserta dibagi dalam 2 kelompok dengan anggota setiap kelompok adalah 5 siswa untuk diminta pembahasan beragam kasus yang biasa dialami di sekolah. Siswa juga diminta mengungkapkan pendapatnya terkait kegiatan role play yang sudah dilaksanakan e) Simulasi dan Latihan, yaitu 
pelaksanaan kegiatan berupa pelaksanaan kegiatan secara langsung sesuai dengan permasalahan yang ingin diperankan siswa sebagai konselor dan konseli. Didalam simulasi, proses pelaksanaannya adalah memerankan suatu situasi nyata yang akan dihadapi peserta saat ini. Adapun gambaran alur pelaksanaan kegiatan pelatihan konselor sebaya adalah tertera pada gambar 1.

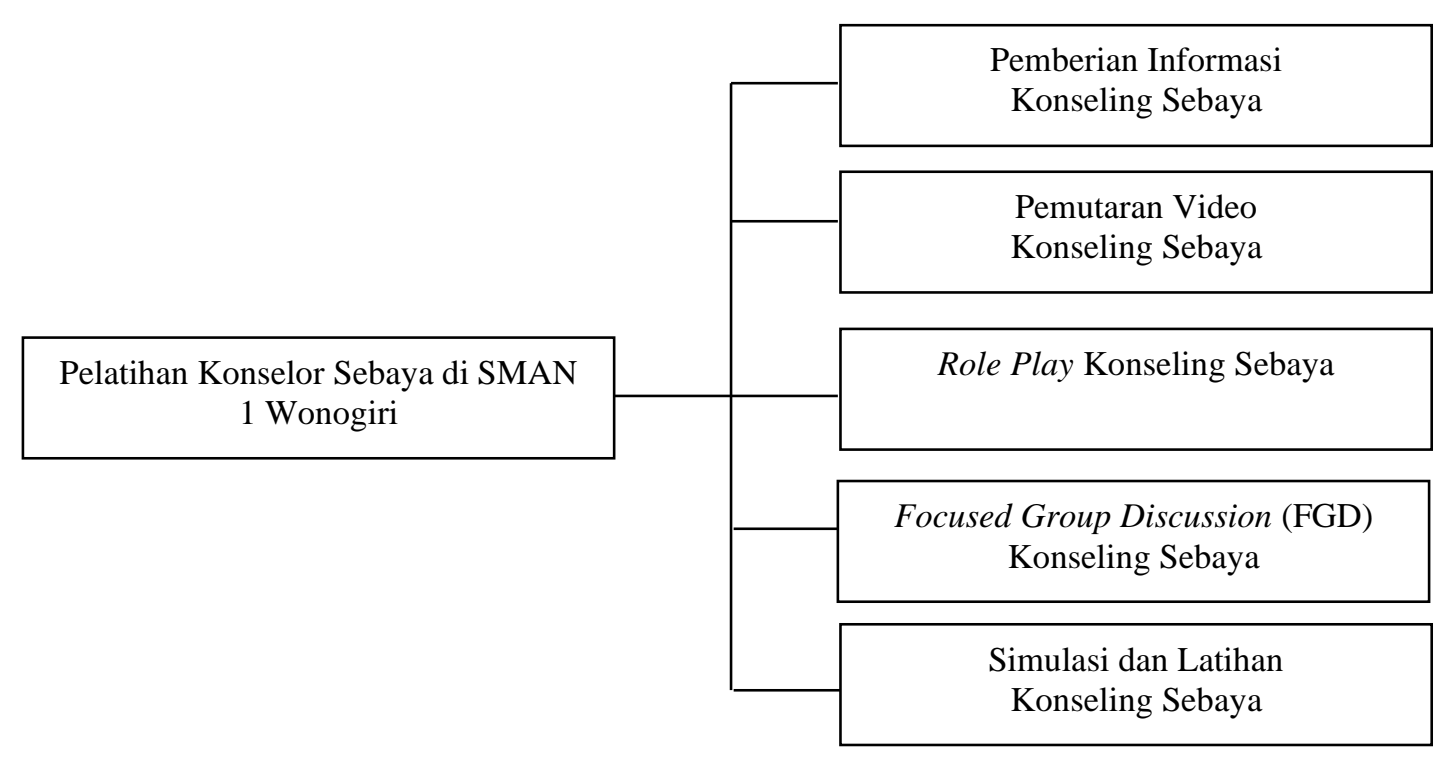

Gambar 1. Alur Pelaksanaan Pelatihan Konselor Sebaya di SMAN 1 Wonogiri

\section{HASIL DAN PEMBAHASAN}

Peserta pelatihan Pelatihan Konselor Sebaya di SMAN 1 Wonogiri dibagi menjadi dua kelompok dengan masing-masing kelompok terdiri dari 5 orang siswa. Setiap perwakilan kelompok yang terdiri dari dua orang memerankan diri menjadi konselor sebaya dan konseli dan melaksanakan kegiatan konseling sebaya. Anggota kelompok yang lain akan memberikan evaluasi, dan refleksi pelaksanaan simulasi sehingga kemampuan siswa sebagai konselor sebaya dapat meningkat. peserta berperan sebagai seorang konselor dan satu peserta lainnya berperan sebagai konseli yang memiliki suatu permasalahan, sedangankan peserta lain berpera sebagai penonton. Proses simulasi itu berlangsung secara bergiliran, sehingga semua peserta akan terlibat dalam proses simulasi. e) Refleksi; Kegiatan ini merupakan bagian dari evaluasi kegiatan yang bertujuan untuk mengetahui tingkat pemahaman peserta terkait dengan materi kegiatan konselor sebaya.

Langkah-langkah

pelaksanaan pengabdian masyarakat dalam bentuk pelatihan konselor sebaya pada siswa kelas XI SMAN 1
Wonogiri menggunakan zoom meeting di era pandemi covid-19 melalui beberapa tahapan yaitu: a) Persiapan; Tim pengabdian masyarakat Prodi Bimbingan dan Konseling Universitas Veteran Bangun Nusantara Sukoharjo mengajukan perijinan dan memberikan penjelasan kepada pihak SMAN 1 Wonogiri mengenai kegiatan pelatihan konselor sebaya. b) Sosialisasi; Tim pengabdian masyarakat memberikan penjelasan kepada sekolah mitra terkait mekanisme kegiatan pelatihan konselor sebaya dan membuat surat kesanggupan peserta pelatihan konselor sebaya untuk mengikuti kegiatan pelatihan konselor sebaya secara penuh dan bertanggungjawab c) Pelatihan dasar; siswa yang telah terpilih secara sukarela mengikuti kegiatan pelatihan konselor sebaya yang dilaksanakan selama 4 hari yaitu mulai tanggal 02-05 Desember 2020.

Pelaksanakan pelatihan konselor sebaya dilaksanakan bertahap selama 4 hari dengan tujuan terbentuknya pemahaman dan ketrampilan melaksanakan konseling sebaya, peserta pelatihan akan mendapatkan sertifikat pelatihan konselor sebaya dan setelah selesai pelatihan para peserta diminta mengaplikasikan kemampuan 
menjadi konselor sebaya, d) Pendampingan; Tim pengabdian masyarakat melakukan pendampingan kepada kelompok konselor sebaya berupa melakukan kegiatan konseling sebaya di sekolah secara daring dan akan didampingi ketika mengalami kesulitan dalam pelaksanaan konseling sebaya, e) Evaluasi; Tim pengabdian masyarakat mengevaluasi pelaksanaan kegiatan pelatihan konselor sebaya untuk melihat kemajuan dan penerapan konseling sebaya di sekolah dan perumusan pengembangan kegiatan dan perluasan kelompok di masa depan.

Pelatihan konselor sebaya pada siswa kelas XI SMAN 1 Wonogiri menggunakan zoom meeting di era pandemi covid-19 sebaya telah dilaksanakan dengan baik dan lancar. Pelaksanaan Kegiatan pelatihan konselor sebaya melalui tahapan sebagai berikut:

Persiapan, Kegiatan persiapan meliputi : a) Menentukan lokasi (sekolah yang menjadi mitra pengabdian masyarakat) dan menentukan peserta yang menjadi sasaran pelaksanaan kegiatan konselor sebaya. b) Melaksanakan sosialisasi dengan SMAN 1 Wonogiri untuk melaksanakan koordinasi kegiatan pelatihan konselor sebaya c) Melaksanakan pelatihan kepada mahasiswa yang membantu kegiatan pelatihan konseling sebaya. Tim pengabdian masyarakat melibatkan 2 mahasiswa menjadi pendamping kegiatan pelatihan konselor sebaya, d) Mempersiapkan e-materi pelatihan konselor sebaya yang akan diberikan kepada siswa peserta pelatihan dan sekolah mitra.
Pelaksanaan, pelaksanaan kegiatan pelatihan konselor sebaya antara lain: a) Pembuatan e-materi konseling sebaya; e-materi berisikan tentang petunjuk praktis dalam melakukan konseling sebaya. Modul ini dalam bentuk pdf sehingga memudahkan siswa mempelajarinya dimanapun dan kapanpun. b) Pelatihan dasar; Pelatihan dasar meliputi pelaksanaan pelatihan konseling sebaya untuk siswa kelas XI SMAN 1 Wonogiri. Tujuan dari kegiatan pelatihan konselor sebaya pada siswa kelas XI SMAN 1 Wonogiri menggunakan zoom meeting di era pandemi covid-19 adalah memberikan informasi mengenai konselor sebaya dan memberikan bekal ketrampilan menjadi konselor sebaya di SMAN 1 Wonogiri untuk menjadikan konselor sebaya sebagai perpanjang tangan layanan BK di sekolah untuk membantu memecahkan permasalahan teman sebaya melalui bekal informasi dan ketrampilan konseling sebaya. Pelaksanaan kegiatan pelatihan konselor sebaya dilaksanakan mulai tanggal 2-5 Desember 2020.

Tahap 1 (hari pertama) : Pertemuan pertama dilaksanakan dengan sharing dan tanya jawab beberapa peserta pelatihan diminta untuk menyampaikan pengalaman selama menerima layanan bimbingan dan konseling di masa pandemi covid-19, hal ini dilakukan mengingat pelaksanaan layanan BK di masa pandemi covid sulit dilaksanakan secara konvensional. Hari pertama yaitu kegiatan sharing dan tanya jawab dilaksanakan oleh Ibu Dra. Awik Hidayati, M.Si

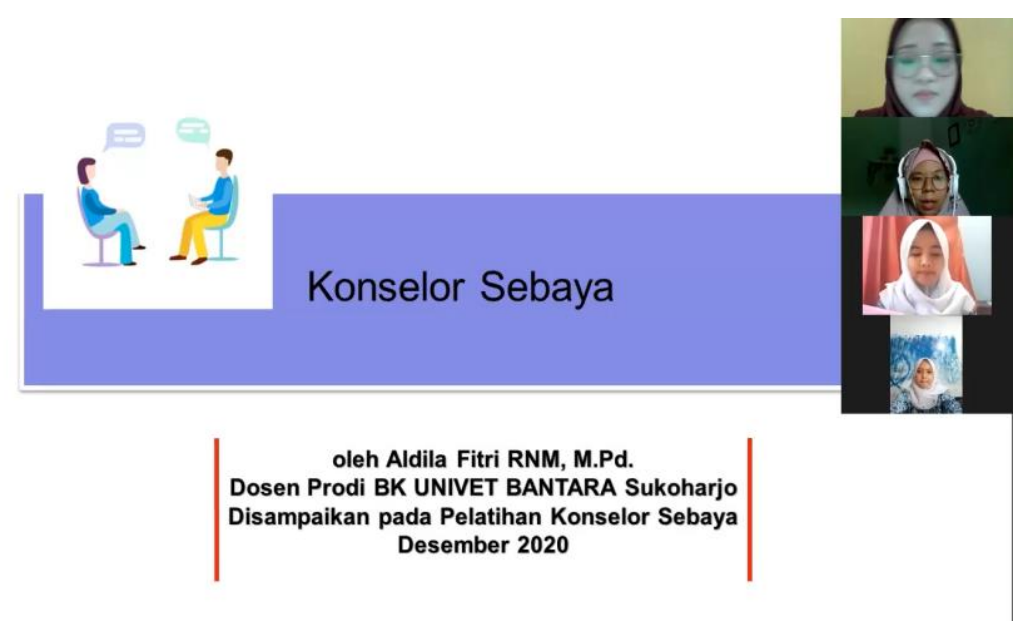

Gambar 2. Penyampaian Materi Konselor Sebaya 
Tahap 2 (hari kedua) : Pemberian materi mengenai konselor sebaya. Materi disampaikan dalam bentuk ceramah mengenai materi konselor sebaya, diskusi, memberikan contoh kegiatan konselor sebaya melalui video dan melaksanakan praktik dalam bentuk role-playing sebagai konselor dan konseli. Hari kedua yaitu pemberian materi mengenai konselor sebaya dilaksanakan oleh Ibu Aldila Fitri R.N.M, M.Pd.

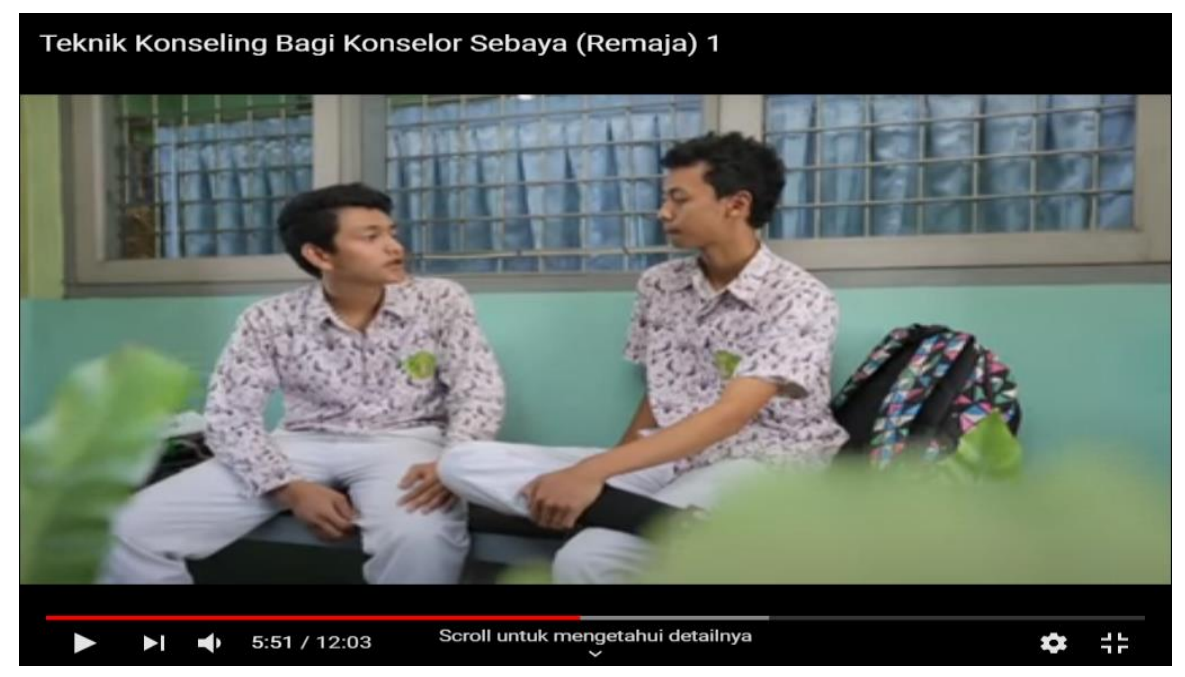

Gambar 3. Pemutaran Video Konselor Sebaya

Tahap 3 : Praktik dan pendampingan pelaksanaan konselor sebaya. Tahap ini diisi kegiatan kasuistik, yaitu pembahasan beragam kasus yang sudah ditangani selama sesi praktik di sekolah, praktik lanjutan konselor sebaya melalui zoom dan Follow up. Pada tahap ini siswa peserta pelatihan mempraktikan menjadi konselor sebaya dengan memilih permasalahan sesuai dengan kasus yang sering muncul di sekolah. Hari ketiga yaitu Praktik dan pendampingan pelaksanaan konselor sebaya dilaksanakan oleh Ibu Mahmuddah Dewi Edmawati, M.Pd.
Tahap 4 : Mengevaluasi hasil dari praktik konselor sebaya. Evaluasi praktik konselor sebaya diperlukan guna melihat kemampuan dan kecakapan siswa peserta pelatihan setelah diberikan pelatihan konselor sebaya selama 4 hari. Hari keempat yaitu hasil dari praktik konselor sebaya dilaksanakan oleh Ibu Mahmuddah Dewi Edmawati, M.Pd dan Ibu Aldila Fitri R.N.M, M.Pd. Untuk memastikan peserta pelatihan konselor sebaya telah mampu melaksanakan tugas menjadi konselor sebaya maka dibutuhkan kegiatan pendampingan.

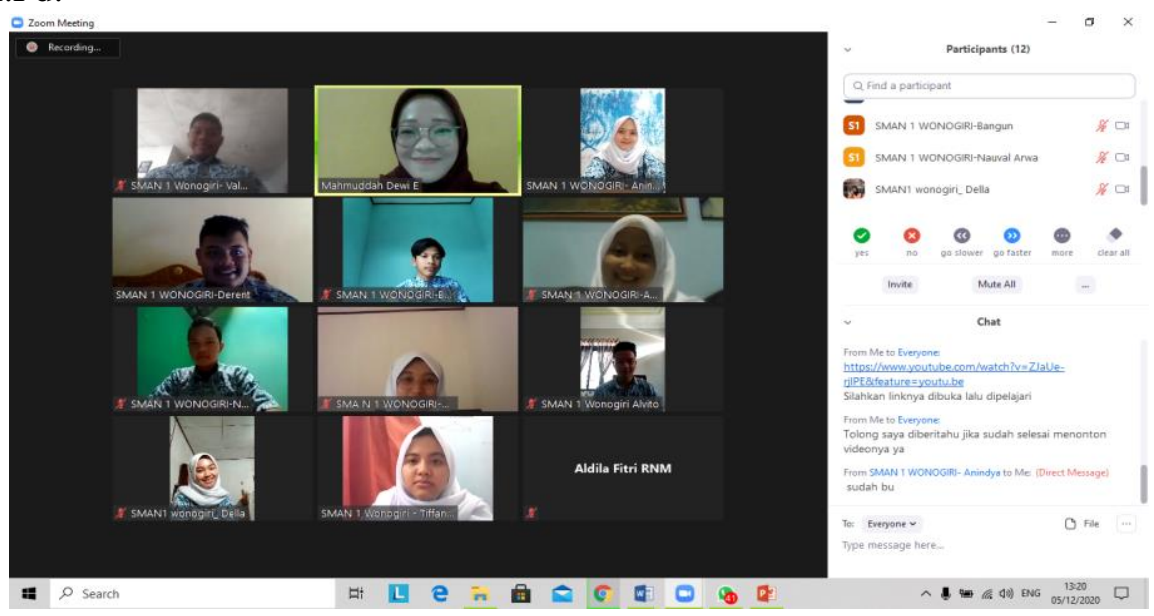

Gambar 4. Pelaksanaan Praktik Konselor Sebaya dan Evaluasi 


\section{SIMPULAN DAN SARAN}

Pelatihan konselor sebaya pada siswa kelas XI SMAN 1 Wonogiri menggunakan zoom meeting di era pandemi covid-19 bertujuan memberikan informasi mengenai konselor sebaya dan memberikan ketrampilan konselor sebaya kepada siswa di SMAN 1 Wonogiri. Pelatihan ini juga memberikan informasi mengenai layanan bimbingan dan konseling, meningkatkan kemampuan menjadi konselor sebaya, dan menjadikan konselor sebaya sebagai perpanjang tangan layanan BK di sekolah untuk membantu memecahkan permasalahan teman sebaya. Pelatihan konselor sebaya pada siswa kelas XI SMAN 1 Wonogiri dilaksanakan selama 4 hari yaitu 02 - 05 Desember 2020. Lebih lanjut pelaksanaan pelatihan konselor sebaya disarankan tidak hanya kepada siswa SMA namun juga siswa SMP dan Sekolah Dasar untuk membantu penyelesaian masalah siswa melalui peran teman sebaya.

\section{UCAPAN TERIMAKASIH}

Ucapan terimakasih kami sampaikan kepada pihak-pihak yang berperan dalam pelaksanaan Pelatihan Konselor Sebaya Pada Siswa Kelas XI SMAN 1 Wonogiri Menggunakan Zoom Meeting Di Era Pandemi Covid-19 yaitu pihak LPPM Universitas Veteran Bangun Nusantara Sukoharjo, Sekolah Mitra SMAN 1 Wonogiri, serta tim Dosen Pengabdian kepada Masyarakat Prodi Bimbingan dan Konseling Universitas Veteran Bangun Nusantara Sukoharjo.

\section{DAFTAR PUSTAKA}

Habsy, B. A. (2017). Filosofi Ilmu Bimbingan Dan Konseling Indonesia. Jurnal Pendidikan (Teori Dan Praktik), 2(1), 1. https://doi.org/10.26740/jp.v2n1.p1-11

Prasetiawan, H. (2016). Konseling Teman Sebaya (Peer Counseling) untuk Mereduksi Kecanduan Game Online. Counsellia:Jurnal Bimbingan Dan Konseling, 6(1), 1-13.

Ridha, A. A. (2019). Penerapan Konselor Sebaya dalam Mengoptimalkan Fungsi Layanan Bimbingan Konseling di Sekolah. Jurnal
Psikologi, $\quad$ 15(1), 25. https://doi.org/10.24014/jp.v15i1.6549

Ridha, M. (2012). Hubungan antara body image dengan penerimaan diri pada mahasiswa aceh di yogyakarta. Empathy, 1, 111-121.

Salmiati, S., Hasbahuddin, H., \& Bakhtiar, M. I. (2018). Pelatihan Konselor Sebaya Sebagai Strategi Pemecahan Masalah Siswa. MATAPPA: Jurnal Pengabdian Kepada Masyarakat, $\quad$ l(1), 36. https://doi.org/10.31100/matappa.v1i1.117

Santrock, J. W. (2002). Life-span Development Perkembangan Masa Hidup Edisi Kelima. Jakarta: Penerbit Erlangga

Sarmin. (2017). Konselor Sebaya : Pemberdayaan Teman Sebaya dalam Sekolah Guna Menanggulangi Pengaruh Negatif Lingkungan. BRILLIANT: Jurnal Riset Dan Konseptual, 2(1), 102-112.

Shohib, M., Firmanto, A., Kusuma, W. A., \& Martasari, G. I. (2016). Pendampingan Kelompok Konselor Sebaya di Kota Batu. Jurnal Dedikasi, 13, 34-38. http://ejournal.umm.ac.id/index.php/dedikas i/article/view/3135\%5Cnhttp://ejournal.um m.ac.id/index.php/dedikasi/article/downloa $\mathrm{d} / 3135 / 3773$

Suranata, K. (2013). Pengembangan Model Tutor Bimbingan Konseling Sebaya (Peer Counseling) Untuk Mengatasi Masalah Mahasiswa Fakultas Ilmu Pendidikan Undiksha. JPI (Jurnal Pendidikan Indonesia), 2(2), 255-263. https://doi.org/10.23887/jpiundiksha.v2i2.2170

Zamroni, E., \& Rahardjo, S. (2015). Manahemen Bimbingan dan Konseling Berbasis Permendikbud Nomor 111 Tahun 2014. Jurnal Konseling GUSJIGANG, 1(1), 1-11. 